\title{
On the Inheritance Strategy of Excellent Chinese Traditional Culture of Overseas Chinese under the Background of Network Teaching
}

Yufeng $\mathrm{Wu}$

College of Chinese Language and Culture, Jinan University, Guangzhou 510610, Guangdong Province, China

\begin{abstract}
In order to better help overseas Chinese students master this communication tool, inherit culture, maintain their cultural habits, and keep the root of overseas Chinese, we deeply study a series of strategies of Chinese online teaching, in order to better help them maintain their national characteristics. Starting from the difficulties faced by overseas Chinese in inheriting Chinese excellent traditional culture, this paper takes festivals, totem beliefs, diet and other traditional culture as examples to analyze the inheritance strategies of overseas Chinese excellent traditional culture under the background of network teaching.
\end{abstract}

Key words: Chinese students; National cultural heritage; Online strategy

Publication date: December, 2020

Publication online: 31 December, 2020

"Corresponding author: Yufeng Wu, 2436756865@ qq.com

In the course of five thousand years of civilization and history, the Chinese nation has created a splendid culture. Overseas Chinese are an important part of the Chinese people, and also an important descendant of the dragon. In daily Chinese teaching, teachers have the responsibility to help overseas Chinese inherit the excellent traditional Chinese culture. Under the traditional teaching mode, the limitation of tools and the influence of the concept of "emphasizing tools and neglecting humanities" lead to the obvious shortage of teachers in Chinese education. It is difficult for students to gain traditional cultural heritage through learning, and more importantly, they are overcoming difficulties to master this language tool. In teaching practice, the author found that the development of teaching technology has solved these problems.

\section{Online festival culture inheritance strategy}

Festival, a kind of folk culture, is created by people to meet the needs of production and life. The rich festival culture formed by various nationalities is an important part of the world folk culture ${ }^{[1]}$. In the practice of life and production, there will be many commemorative days. The Chinese Spring Festival is a common festival of the Chinese nation, and also one of the most important festivals. The celebration forms are diverse and have a long history. The development of online teaching mode can make more effective use of class time and solve the problem of teacher shortage.

\subsection{Wechat interaction, delivering Spring Festival blessings}

With the help of online teaching system, Chinese teachers can comprehensively present the spring festival culture, and celebrate the festival with the help of Wechat platform, so as to help students build more perceptual experience, and promote overseas Chinese teenagers to better experience and learn traditional culture ${ }^{[2,3]}$. First of all, there are a lot of information resources about Spring Festival celebrations on the Internet. Chinese teachers can share them with students for watching after class, so as to improve the utilization of classroom time. For example, the red envelope is one of the important celebrations of the Spring Festival, which originated from the legend of new year's beast. On the eve of 
New Year's Eve, the ancients wrapped the money in red paper and put it under the child's pillow, in order to scare away the new year's beast and protect the child's health. With the development of the times, the purpose of people's red envelope is no longer to prevent the new year beast from making children feverish, and the time of sending red envelope is mostly the days at the beginning of the year. The cultural connotation of expressing blessing and concern through this form has been handed down. These interesting stories and life scenes can be shared with students as micro lesson learning materials. Secondly, Wechat platform launched the Spring Festival red envelope service, the amount is not large, but the red envelope form design of China red, full of blessing and care, is a good teaching work. In the process of Chinese teaching, we can play the video of celebrating the Spring Festival with physical red envelopes for students, and send them red envelopes through Wechat platform, so that overseas Chinese far away on the other side of the ocean can really feel the spring festival culture, and drive them to convey new year's wishes and goodwill to their relatives and friends through red envelopes, so as to maintain their cultural habits and inherit and promote the national culture.

\subsection{Pasting Spring Festival couplets to cultivate national cultural habits}

Spring Festival couplets, also known as couplets, spring stickers and door couplets, are an indispensable cultural feast for the Chinese New Year and a unique festival celebration form in China. Spring Festival couplets are a form of expression written on big red paper, which are concise, exquisite and neat. It is not only an elegant national culture, but also an auspicious culture deeply rooted in the bone marrow of Chinese. Red Spring Festival couplets symbolize people's expectation for a better life. With the help of online teaching system, teachers can broadcast the process of pasting Spring Festival couplets at home for students, and let students feel a strong taste of new year through life teaching materials. Secondly, students show their own Spring Festival couplets. The online display of Spring Festival couplets will give students a stage to express themselves, and turn them from onlookers to participants. In the bustling activities of pasting Spring Festival couplets, overseas Chinese students not only feel the taste of new year, but also promote the inheritance of national cultural habits through their own behavior of pasting Spring Festival couplets.

\section{Strategies of telling totem stories in micro class}

The Chinese people call themselves the descendants of the Yellow River and the descendants of the dragon. The worship of the dragon totem has continued from ancient times to the present. In the process of inheriting this culture, many idioms, stories and images of the dragon have been formed, which are the inheritance of the concept of totem ancestors. These idioms have been used in daily life, and it is not difficult to see the case of dragon image as decoration in all kinds of objects. Overseas Chinese are not only an important part of the Chinese people, but also an important descendant of the dragon.

Language, as a tool of communication, has a distinct national cultural brand. In the Chinese system, there are many idioms about dragon, such as Ye Gong's love of dragon, the spirit of dragon and horse, the context, the finishing touch, and so on. In life, there are many things decorated with the image of dragon. For example, the finishing touch evolved from the story of Zhang sengyou's painting for a temple. It is one of the most commonly used idioms in modern times to compare "people speak or write articles, point out the gist with a key and incisive sentence or two in the main points, deal with the key parts well, so as to make the overall effect more vivid". First of all, with the help of micro lesson video, Chinese teachers can present the Dragon Story and the image of the dragon to help overseas Chinese students better understand the dragon culture. Secondly, we can play the relevant video frequency band ${ }^{[2]}$ to help students explain the application context of this idiom, so as to promote students to have a deeper understanding of Chinese language culture and totem culture.

\section{Classroom strategies of online food culture}

\subsection{The history of chopsticks presents the national thinking.}

Life is not only the carrier of culture, but also the soil of its birth. In daily teaching, Chinese teachers can use the air classroom technology to help them 
understand the splendid life culture created by their ancestors and the application of these splendid cultures in today's life, so as to better meet the learning needs of students.

With 5000 years of civilization, the Chinese nation has unique views on the development and utilization of food sources. Even food utensils contain rich genes of traditional culture. Learning Chinese characters is the basis of mastering Chinese. First of all, chopsticks in ancient times were also called chopsticks. They were mostly made of bamboo, and the bamboo prefix was used to express sound and meaning. The meaning of the tool to help eat, also called Jia and Qian, was composed of the following characters. Teachers can show the real chopsticks through video, and explain the writing method and meaning of chopsticks for students. Secondly, because "Tuo he Zhu" is a homophonic word with the meaning of "stop". We think it is unlucky. We call this tool "chopsticks". We use the antonym "stop" to express our hope for a better life. The evolution history of the name "chopsticks" can also be described through this, so as to improve their humanistic and cultural quality. Finally, Chinese teachers can present the story of bamboo, the material for making chopsticks, and the evolution of this character from oracle bone inscriptions to modern running script to students through the air class, so as to help students better understand the development of hieroglyphics, and help students remember this tool and chopsticks in a more vivid way, and understand chopsticks culture.

\subsection{The shape of chopsticks reflects the philosophy of life.}

"No rules, no square". The circle and square at both ends of chopsticks reflect the simple world outlook of Chinese ancestors, and also reflect people's respect for rules. With the help of air classroom technology, Chinese teachers can show students chopsticks and introduce them to the following topics: "Our ancestors applied the cosmology of" heaven is round and place "to the shape of chopsticks. The circle symbolizes the heaven and the square." So as to help students understand the development history of philosophy embodied in the Chinese tableware, and let students have a more concrete understanding of the development of their own national philosophy. Secondly, teachers can combine the facts of life with students' discussion, observe the internal relationship between rules and freedom, help students understand the life philosophy reflected by chopsticks, and let national culture permeate students' life words and deeds.

\section{Conclusion}

In short, festivals, folk customs, stories and other traditional cultures are the most widely used cultural forms in life, which are relatively close to the perceptual experience of young students' life. With this form as the carrier to help overseas Chinese teenagers learn Chinese characters, words and ideas, they will be more willing to accept them, and the teaching efficiency will be significantly improved. Information technology has more diverse ways to show things, online teaching has more ways to spread Chinese traditional culture, and Chinese teachers have more extensive teaching design ideas, which is an excellent teaching way to reduce learning pressure and improve teaching quality. With the rapid development of information technology in China, online teaching will be more convenient. With the help of tools, Chinese teachers can create more teaching models that are closer to Chinese students.

\section{References}

[1] Liu HJ. Analysis on the teaching content and mode of excellent traditional culture [J]. Writer World, 2020(10): 98-99.

[2] Cai L, Chen Y. Research on Chinese online multimedia teaching resources in Singapore $[\mathrm{J}]$. Overseas Chinese Education, 2018(3): 100-110.

[3] Zhang FF. A preliminary study on the network new language teaching of Chinese education[J]. Times Literature (second half), 2012(1): 205-206. 